\title{
Technological Globalization and Academic Staff Development in Tertiary Institutions in Rivers State, Nigeria
}

\author{
Sotonye Soye Asawo \\ Department of Educational Management, Ignatius Ajuru University of Education, \\ Port Harcourt, Nigeria
}

\begin{abstract}
This study investigated Technological Globalization and Academic Staff Development in Tertiary Institutions in Rivers State, Nigeria. It was undertaken to determine the influence of technological globalization on academic staff development in tertiary institutions in Rivers State. Two research questions and two hypotheses guided the study. The correlational research design was adopted for the study. A sample of 145 out of the population of 1,454 academic staff from the four Rivers State owned tertiary institutions was randomly selected. The method of data collection was the questionnaire titled 'Technological Globalization and Academic Staff Development Questionnaire' (TGASDQ). The instrument was validated by experts and a reliability coefficient of 0.766 was obtained. The data were analyzed with both descriptive (Mean) and inferential statistics (Pearson Product Moment Correlation co-efficient (r). The study found that there is a low, positive and significant correlation between technological globalization and academic staff development in tertiary institutions in Rivers State. The study concluded that academic staff of the institutions need to evolve and align themselves with the benefits of technological globalization, and therefore recommended that educational managers and administrators should consciously, enhance their advancement centres and develop functional ICT centres for academic staff development.
\end{abstract}

Keywords: Globalization, Technological Globalization, Academic Staff Development (ASD), Continuous Professional Development (CPD), Research Advancement, Tertiary Institutions

DOI: $10.7176 / \mathrm{JEP} / 12-18-01$

Publication date:June $30^{\text {th }} 2021$

\section{Introduction}

The human being is a nation's most important resource, and is therefore central to its economic development (Okoli, 2013). In every sphere of life, the human being is the most priced resource because the human resource largely determines the level of productivity in any system. Even in a digital age, the human resource is still the driving force of every organization. As in any other organization, the human resource is the most valuable asset in educational institutions and is vested with the responsibility of grooming students who will contribute to the all-round development of the nation. Educators and trainers are especially important because they are charged with the responsibilities of developing the human assets by inculcating learners with knowledge, skills and competencies to address current and future challenges.

Overtime however, the educators themselves diminish in their capacity to prepare others, thus the need for regular development towards self-improvement. Peretomode \& Chukwuma (2016) pointed out that with age, human beings suffer from diminished vitality, creativity and flexibility. This suggested that with the passage of time, at the different stages of their career circle, lecturers in tertiary institutions need to be assisted to remain vibrant, vital and productive. These authors found that in tertiary institutions where lecturers have the opportunity of training or self-renewal on the job, even though such development efforts do not ensure automatic promotion, it increases lecturers' productivity. Olu (2012: 483) is of the view that "teachers who shoulder the responsibility of training the young ones need to be developed to be able to perform their role, up-grade and update their competency within the school system". This is particularly important for tertiary education because according to the World Bank, "Education in general and higher education in particular, are fundamental to the construction of a knowledge economy and society in all nations (Jelilov, 2016: 1863).

To ignore the developmental efforts of the academic staff who are critical actors in the educational sector is to ignore the core of the sector, which may lead to crises and a disorganized system with grave consequences. One factor that seems to have become a serious consideration for determining why and how the human resource, especially in the educational sector should be developed is globalization. This is captured in the argument of Pargaru, Gherghina and Duca (2009) as follows:

We are living in a society dominated by change. The technical, economical and social evolution has shaped people's way of living and thinking. The globalized markets, the technical and technological revolutions are transforming the modern economy into a "knowledge based society" in which new ways of organizing the work are governing the world, demanding a perpetual buildup of competences, a rapid spread of high performance 
technologies, solid knowledge and increasing responsibilities (p.646).

The world is today experiencing a greater level of interconnectedness and interdependence than it had ever witnessed in history. This is as a result of competitiveness brought about by globalization in the world's economy. Today, what happens in one part of the globe affects other parts and this has been facilitated by the advances in information and communication technology (ICT). Educational revolution which has been heightened by Technological Globalization is increasingly changing the learning process in higher education through improved facilities to educational resources. Furthermore, the global environment which has eased communication with almost anyone in the world, at any time and about any topic is positioning educators to provide the training and instruction needed to thrive in the global space, preparing the students for successful transmission into global work environments, with expanded global perspectives.

Every nation is therefore expected to be positioned to take full advantage of the gains of technological globalization in enhancing the quality of its education to be able to compete favorably with its counterparts all over the world. But how has Nigerian educational sector fared in taking advantage of the gains of technological globalization to address the manpower development needs? This is the focus of this study.

\section{Statement of the Problem}

The issue of decline of standard though multifaceted, is hugely linked to the quality of the manpower in the educational system. Recent topical issues such as technology, diversity, etc. have become a challenge facing tertiary education teachers, and places on them the responsibility to be ahead of the learners by staying in touch with the latest trends in the field of teaching and learning. There is therefore the need for constant development, not only for the staff members to perform their assigned duties, but also to keep them abreast about the changing and new trends in their chosen fields and the advancement of their careers. But sadly, there seem to be a problem with academic staff development in tertiary institutions in Nigeria (Rivers State being no exception). It is often speculated that funding may have been a major challenge, with staff development not receiving adequate budgetary provisions, leading to sustained agitations by the Academic Staff Union of Universities (ASUU).

- Scholars had argued that staff development is central to the quality of higher education, but the way it is considered and delivered at present owes a lot to the general employment framework and conditions of service for staff of higher institutions. There seem to be a major shortfall in the effort and funding devoted to staff development of all kinds. Whilst globalization has increased the need for staff development, it has equally created newer avenues for academic staff to be better equipped for their task. There is however little evidence to suggest that universities in Nigeria have taken advantage of these avenues of staff development. This is the gap that this study seeks to address. The major consideration in this regard is assessing the role of technological globalization in determining the extent of staff development programmes in tertiary institutions in Rivers State.

\section{Purpose of the Study}

This study determined the influence of technological globalization on academic staff development in tertiary institutions in Rivers State. The specific objectives of the study were to:

1. Determine how technological globalization influences continuous professional development in tertiary institutions in Rivers State.

2. Determine how technological globalization influences research advancement in tertiary institutions in Rivers State.

\section{Research Questions}

The following research questions guided the study:

1. How does technological globalization influence continuous professional development in tertiary institutions in Rivers State?

2. How does technological globalization influence research advancement in tertiary institutions in Rivers State?

\section{Hypotheses}

The following hypotheses postulated at 0.05 level of significance guided the study:

1. There is no significant relationship between technological globalization and continuous professional development in tertiary institutions in Rivers State.

2. There is no significant relationship between technological globalization and research advancement in higher institutions in Rivers State. 


\section{Review of Related Literature}

\subsection{Theoretical Framework}

The study was anchored on the Human Capital Theory which is traced to Adam Smith in the $17^{\text {th }}$ century, but advanced and made popular by Gary Becker (1962) and Jacob Mincer (1974). Human Capital is the knowledge, skills, and assets employees bring to bear in the form of accumulated knowledge and skills; the set of skills and characteristics that increases a worker's productivity and makes the workplace productive. It is the pull of knowledge and characteristics an employee has which is either innate or acquired that contributes to his or her productivity. Samoszuk (2018) defined Human Capital as the knowledge, skills, assets, and experiences that an individual has which add value to a company. This definition suggests that all employees do not add the same value, rather value added depends on the knowledge, skills, and assets of the individual worker, which is premised on such factors as the person's experiences, tenure, education, training, and health. The theoretical framework mostly responsible for the wholesome adoption of education and development policies has come to be known as human capital theory (Almendarez, 2011).

These skills are acquired through investments in education and training and enhances the potentials and income earnings. It brings education closer to the logic of market competition, constituting the logic of selfgovernance based on economic costs and benefits. Here the assumption is that an individual's level of human capital is positively associated with income. Specifically, On-the-job training is a great way to invest in human capital. Even with acquired basic or entry education, many employees still need additional training to be skilled at their job. Human capital theory stresses the significance of education and training as the key to participation in the new global economy where hard tangible assets may not be as important as investing in human capital.

Scholars have opined that the human capital theory can be applied in every formal organization, from government parastatals even to educational institution even though it comes from neoclassical economics. This is captured by Samoszuk (2018) who stated that human capital is a key determinant of economic success in all industries, and Tan (2014) with the opinion that human capital theory has had a profound impact on a range of disciplines from economics to education and sociology. Also, the simple economist (2017) stated Human capital theory is relatively consistent across different disciplines and that its role is widely discussed in economic development, productivity analysis, innovation, public policy, and education.

\subsection{The Concept of Globalization}

Onodugo in Aina and Reuben (2014) stated that there exists a huge body of literature on the subject of globalization and its attendant implications on the socio-economic and political welfare of nation states. He buttressed that the term has different facets, mostly seen in terms of economic and technological forces with huge effects on both the social and political sphere. The Merriam-Webster Dictionary (2017) defines Globalization as "the act or process of globalizing; the state of being globalized, especially the development of an increasingly integrated global economy marked especially by free trade, free flow of capital, and the tapping of cheaper foreign labour markets". It is about interconnecting people around the world beyond the physical barrier of geographical boundaries. Globalization is multifaceted and associated with consequences at the economic, political and socio-cultural levels.

Columbus (2018) opined that globalization is used and defined in many contexts. Economically, globalization is used to denote the free movement of goods, services and capital across the world, where countries are open to trade and foreign investments of other countries, taking advantage in areas they have an edge. Socially, it entails a liberation of a nations' visa rules and procedures in order to facilitate free movement of people from nation to nation. In whatever context it is used, the concept of globalization makes nations open up their economies to trade, foreign investments, movement of people, goods and services, and leveraging on areas with comparative advantages. It is extending to other or all parts of the world. The multifaceted nature of globalization makes it cut across people, companies, governments etc. with proof and impact on the environment, culture, political coloration, economic development and the physical well-being of nations across the globe.

Similarly, Holland and Holland (2010) defined the term as the process of transnational dissemination of ideas, languages, economies and cultures throughout the international community. This is necessitated by increase in world travels, immigration and communication technology, which has made the world become more interconnected and interdependent. With globalization, the exchange of goods, capital, services, education, information, technology and labour has been on the increase. Buttressing the above positions, Ojedele, Oyekan and Oresajo (2015) emphasized that globalization is one fundamental change occurring at a global level. According to them, globalization is the integration of national, economies, culture, social life, technology education and politics; and the movement of people, ideas and technology from one place to another. The definitions considered above point to the fact that the wave of globalization has the characteristics of encompassing social, political, economic, technological and cultural landscape, shrinking time and space, and bringing about profound advances in communication, transportation and infrastructure.

Olotu (2013) posited that globalization is generally seen to mean: 
- Internationalization which deals with cross border relationships among countries, giving rise to increase in international exchange and interdependency

- Liberalization in the areas of removal of restrictions on movement imposed by governments, leaving room for a borderless world economy

- Universalization : disseminating of information to people everywhere with the use of computers and television

- Modernization: the spread of modernity all over the world in the form of capitalism, rationalism, industrialism, bureaucratism, etc. which is intended to displace the culture of localized self determination

- Deteritorialization which refers to the temporal compression of distance by making porous state boarders.

The dawn of the industrial revolution in Europe necessitated that new markets be sourced to dispose the excess goods and for the purchase of raw materials for the booming industries. But the volume of trade and other services increased significantly following the growth in technology, information and transportation. Technology, brought to the fore the modern wave of globalization. The two waves of globalization are industrial revolution induced globalization, leading to the development of railways, steamships, telephones and telegraphs, reduction in transportation and communication, and ICT induced globalization with emphasis on information, communication and technology. This is corroborated by the Levin Institute in (2016) that technology has been the other principal driver of globalization. The institute states that advances in information technology, in particular, have dramatically transformed economic life. Information technologies have given all sorts of individual economic actors - consumers, investors, businesses - valuable new tools for identifying and pursuing economic opportunities, including faster and more informed analyses of economic trends around the world, easy transfers of assets, and collaboration with far-flung partners.

\subsection{Technological Globalization:}

Information technology has been the catalyst for globalization by creating efficient and effective channels to exchange information (Aziz, in Aina and Reuben, 2014). Technology can be defined as the socialized knowledge of producing goods and services and can be described with five important elements: production, knowledge, instruments, possession and change. The term technology is applied to the tools, machines, and processes that use scientific advances in practical applications. One major factor that has contributed to globalization is technological change, in particular, the information technology. Technological globalization is the growth of the world through technology. It is advances in our ability to communicate and process information in digital form. It is a series of developments sometimes described as an "IT revolution" which is reshaping the economies and societies of many countries around the world. Information technology provides the communication network that facilities the expansion of products, ideas and resources among nations and people regardless of geographical location. Knowledge and technology provide the current impetus for the present dynamics of globalization. For rapid socio-economic transformation, the information and communication technological capacity of human resource have to be continuously upgraded.

Many technological advancements improve globalization by making people and things in distant places accessible to one another. Boats and Ships as means of transportation made people, things, and information more accessible across seas. The wheel, carts, bicycles, cars and trains made people, things and information more accessible across land. Air crafts made people, things, and information more accessible across the air space. Information Technology makes people, things, and information more accessible across electronic data channels. Technology is the foundation of globalization. Without its participation, the process would not be possible. Technological advances made it possible to establish contacts between people living in different parts of the world. Modern tools of communication and transportation allow companies to conduct business not only locally but also globally.

The eNotes (2011) recorded that technological innovation has opened the doors for an increasingly collaborative global effort in the areas of communication, research, world-wide development, and production. The notes highlighted some advantages and disadvantages of technological globalization. One established positive element of technological globalization is the interconnectivity of the world. Management of the geographical space is not as challenging as it used to be prior to the emergence of technology. Proximity is no longer the central issue in determining buyers and sellers especially in commercial dealings. Information, goods and people can now travel very quickly. News, insights, and communication can spread instantly with the presence of technology. The World Wide Web (www), Twitter, Facebook and Skype indicate how interconnected all aspects of the globalized setting are. People around the world are able to communicate quickly with people all over the world, see things as they actually happen (when there are earthquakes, tsunamis, floods, war, etc.), see projects come to fruition more quickly, special effects are more realistic and just about anything one wants to do can be done faster and better than before due to advances in technology. Another outstanding 
positive news is that acquiring technology (and the ability to use it) can be done on a pretty fast track. It is now possible to become aware of, and respond to business opportunities, humanitarian needs, and natural disasters, that would have gone unnoticed and unanswered by much of the world prior to the advent of technology. People are no longer confined to one location in conducting business, but rather can communicate and conduct commerce with someone anywhere in the world via the internet. This has created a very dynamic sort of economy that grew quickly and has done a great deal to make the world a more equal place through globalization. Technology has made it possible for developing countries, especially India and China to develop in ways that were never accomplished in the days before so much technology.

The down sides of technological globalization include, but not limited to the following: The need for web interconnectivity is essential in the global setting. Thus, areas of the world that are not interconnected are left behind from global competitiveness because of the digital divide which creates some sort of technological elites especially in urban centers, leaving most rural settings behind. The disparity between individuals, cities, and countries who have access to technology and those who do not is a significant problem. The lack of technology literally isolate those who can least afford it to be alienated by progress. Also, technology makes us vulnerable. We have become so dependent on technology to do everyday activities like online shopping, banking, recordkeeping, school registration, data storage, and so on that there is the growing challenge of having our identities stolen, information stolen, and the possibility of being financially decimated in a matter of seconds. Without proper protection (which is difficult to keep up with because of the activities of hackers who are constantly finding ways around firewalls), and the inherent risk of cybercrime. Businesses do not have strong ties to any community and can pack up and leave, sometimes without any notice. Another challenge is that the quick and convenient products one can purchase from all over the globe comes with the difficulty to enforce any sort of quality or safety rules, breaches of security, blatantly false or incomplete information creating problems out of proportion with reality. The world has reverted back to a "caveat emptor" (buyer beware) approach to world commerce, because protecting the consumer has become inherently more difficult. Global terrorism, crime and pornography is spread much easily. The continuous privilege to stay connected with the world brings with it the price of inability and sometimes the unwillingness to take time away to decompress and relax, thereby people increasing their stress level. However, that does not take away from the fact that the lives of millions of people around the world have been improved with the advances in technology.

\subsection{Benefits of Technological Globalization on Education:}

The impact of globalization have been viewed from both the positive and negative angles, not just in education, but in all spheres. Imhonopi and Urim (2014) argued that though there are many disadvantages associated with globalization on Nigeria's educational system such as brain drain, internet crime, plagiarism, and erosion of positive values, one cannot take away the glaring advantages such as the introduction of a paperless economy, easy access to information, diffusion of technology, increased knowledge sharing, inter alia. As noted earlier, one of the major features of globalization is advances in ICT. Scholars like Afonja and Kpakol in Kaegun and Nwikina (2016) posited that improved technology is capable of transforming both students and staff of tertiary institutions, and empowering individuals, organizations and government with tools for opportunities around the world, and accelerate the wealth creation process which can cause developing countries, institutions and organizations to catch up quicker.

Despite the debate on the positives and negatives of globalization, its impact on education has been tangible. The phenomenon has put pressure on both the government and educational leaders and policy makers to become even more competent to avoid economic and financial crisis. Globalization has ensured the possibility for communication with almost anyone in the world about anything and at any time. Educators are not exempted from this opportunity to thrive in a globalized environment. Kaegun and Nwikina (2016:144) identified some important areas where school operators and staff can benefit from globalization as follows:

- Globalization as an all-purpose elixir can bring tremendous benefits and chances in the lives of the members of the school as well as the social service institutions generally.

- Through globalization, the traditional workload that inhibit work and teaching processes is reduced as modern gadgets are used and increases productivity.

- School leaders will improve further in their administrative performance to enhance the efficiency, effectiveness and productivity of higher institutions in today's changing world.

- The globalizing economy and technological change will inevitably place an increasing premium on a more highly skilled labour force.

- Literacy and school enrollments will increase in almost all countries, and lead to a narrowing in the educational gender gap across the world.

- Through globalization, government will take further steps in planning, organizing, coordinating highly skilled workforces, to better themselves by using the computers, communicating effectively, solving problems online, and acquiring entrepreneurial skills and continuously upgrade themselves to keep pace 
with the speed of change in the future.

- Globalization as a complex concept is a sure of improving higher institutions and its clients generally and more so, put pressures on the stakeholders in education to be more committed in their various assignments to place the Nigerian Universities in its proper place in global ranking.

- Lecturers will improve tremendously in their teaching, research and community service to all the stakeholders and will be abreast with current information, knowledge and skills to perform.

- Higher institution staff will be transformed into a global knowledge economy where they have the freedom to compete favorably among themselves and other colleagues outside the country.

\subsection{Academic Staff Development (ASD)}

A motivated work force is a key resource for the success of any organization. A consensus has emerged from literature that points out that professional development can impact positively on teacher knowledge and skills which will result in student achievement if delivered in conducive and supportive settings (Brazer and Bauer, 2013; Buczynski and Hansein, 2010; Ertner and Otteinbreit-Leftwich, 2010; Guskey, 2003 in Chabaya 2015). Professional development is considered to be an institutional strategy which makes curriculum change so imperative in higher education. Lecturers needed to be empowered to deal with the demanding challenges of teaching in higher education and remain professional. Graham and Bennett (1988) opined that training which is primarily aimed at developing staff members has the important dual function of utilization and motivation. It is the responsibility of management to recognize, deploy and promote the potentials of all staff members in ways that make an effective contribution to the objectives of the organization. This is the task of staff development as it involves the development of potentials and the qualification of new and existing staff.

Staff development is an intentional effort by supervisors and administrative leaders to improve staff members' effectiveness which leads to improved effectiveness in organizations. Staff development programmes, which could be formal or informal helps staff members improve on their responsibilities, develop required skills and competencies which are needed to accomplish goals, for personal and professional growth, and for preparation for advancement. It is frequently argued that professional development has the potential to empower university academics with the necessary pedagogical skills for them to cope with educational challenges encountered in higher education. Professional development is seen as an intervention strategy which could capacitate the higher education sector to meet graduate output (Scott, 2008 in Chabaya, 2015). Flippo (1976) opined that development is concerned with the increase in skill through training, which is necessary for proper job performance, and considers it of great importance in the organization due to changes in technology, realignment of jobs, and the increasing complexity of the task of management.

\section{Methodology}

The correlational research design was adopted for the study. A sample of 145 out of the population of 1,454 academic staff from the four Rivers State owned tertiary institutions namely the Ignatius Ajuru University of Education, Rumuolumeni, the Rivers State University, Nkpolu-Oroworukwo, the Kenule Benson Saro -Wiwa Polytechnic, Bori and the Captain Elechi Amadi Polytechnic, Rumuola was randomly selected. The method of data collection was the questionnaire titled 'Technological Globalization and Academic Staff Development Questionnaire' (TGASDQ). The instrument was validated by experts and a reliability coefficient of 0.766 used. 145 copies of the questionnaire were distributed, 131 copies were retrieved and 125 copies were useable, representing $86 \%$. The data were analyzed with both descriptive (Mean) and inferential statistics (Pearson Product Moment Correlation. The analyses were all done with the aid of the Statistical Package for the Social Sciences (SPSS), version 22.

\section{Data Analysis}

\subsection{Demographic Analysis}

The responses showed that $28.0 \%$ of the respondents are Assistant lecturers, $25.6 \%$ are lecturer 2 staff, and lecturer 1 had $8.0 \%$ respondents, while Reader and above had $12.8 \%$. In the years of experience of the respondents, $45.6 \%$ has worked for $1-9$ years, $32.0 \%$ has worked for $10-19$ years and $22.4 \%$ have worked for 20 years and above. In qualification, $6.4 \%$ of the respondents hold a B.Sc., $56.0 \%$ hold a Master's degree while $37.6 \%$ hold a Ph.D. as the highest educational qualification. $78.4 \%$ of the respondents are males, totaling 98 staff and $21.6 \%$ totaling 27 females responded to the questionnaire. 


\subsection{Descriptive Results}

Table 1. Descriptive statistics on technological globalization

\begin{tabular}{|l|r|r|r|r|r|}
\hline & $\mathrm{N}$ & Minimum & Maximum & Mean & $\begin{array}{c}\text { Std. } \\
\text { Deviation }\end{array}$ \\
\hline $\begin{array}{l}\text { I am aware of the different ICT tools that are available to } \\
\text { make my work as an academic easier. }\end{array}$ & 125 & 1.00 & 4.00 & 3.2000 & .97551 \\
\hline $\begin{array}{l}\text { Our institution has acquired the technological equipment } \\
\text { needed to improve teaching and learning. }\end{array}$ & 125 & 1.00 & 4.00 & 2.5520 & .87488 \\
\hline $\begin{array}{l}\text { Our institution has trained me in the use of ICT to aid my } \\
\text { work as an academic. }\end{array}$ & 125 & 1.00 & 4.00 & 2.4720 & .96366 \\
\hline $\begin{array}{l}\text { I have taken full advantage of technology in the } \\
\text { performance of my duties as an academic. }\end{array}$ & 125 & 1.00 & 4.00 & 2.8800 & .81913 \\
\hline Valid N (listwise) & 125 & & & & \\
\hline
\end{tabular}

Source: SPSS Output

In Table 1 above, the mean score of 3.20 show a high awareness of the different ICT tools that are available to make the respondents' work as academics easier. The institutions of the respondents have a high rating with the acquisition of the technological equipment needed to improve teaching and learning with the mean score of 2.55. Also, the mean score of 2.47 indicate an average in the training of the respondents by their various institutions in the use of ICT to aid their work as academics. The mean score of 2.88 show a high rating that the respondents have taken full advantage of technology in the performance of their duties as academics.

Table 2. Descriptive statistics on continuous professional development

\begin{tabular}{|l|r|r|r|r|r|}
\hline & $\mathrm{N}$ & Minimum & Maximum & Mean & $\begin{array}{c}\text { Std. } \\
\text { Deviation }\end{array}$ \\
\hline $\begin{array}{l}\text { I have been encouraged by my institution to pursue a higher } \\
\text { degree since joining its staff membership. }\end{array}$ & 125 & 1.00 & 4.00 & 2.8560 & 1.11950 \\
\hline $\begin{array}{l}\text { Through the exposures I have been exposed to by my } \\
\text { institution, I have established networks of fellow academics } \\
\text { from other countries. }\end{array}$ & 125 & 1.00 & 4.00 & 2.6480 & .90032 \\
\hline $\begin{array}{l}\text { I have attended international academic conference(s) outside } \\
\text { Nigeria. }\end{array}$ & 125 & 1.00 & 4.00 & 2.0800 & 1.16813 \\
\hline $\begin{array}{l}\text { Senior Lecturers and Professors in my institutions go out on } \\
\text { sabbatical leave to other institutions outside Nigeria. }\end{array}$ & 125 & 1.00 & 4.00 & 2.3600 & 1.00322 \\
\hline Valid N (listwise) & 125 & & & & \\
\hline
\end{tabular}

Source: SPSS Output

In Table 2 above, the mean score of 2.85 indicate a high rating by the respondents who have been encouraged by their institutions to pursue a higher degree since joining its staff membership. The mean score of 2.64 also show high rating by the respondents that through the exposures they have been exposed to by their institutions, they have established networks of fellow academics from other countries. Also, the mean score of 2.08 indicate a high rating that the respondents have attended international academic conference(s) outside Nigeria and Senior Lecturers and Professors in the institutions of the respondents go out on sabbatical leave to other institutions outside Nigeria with an average mean score of 2.36 .

Table 3 Descriptive statistics on research advancement

\begin{tabular}{|l|r|r|r|r|r|}
\hline & $\mathrm{N}$ & Minimum & Maximum & Mean & $\begin{array}{c}\text { Std. } \\
\text { Deviation }\end{array}$ \\
\hline $\begin{array}{l}\text { I have benefited from international research grants to fund } \\
\text { my academic research. }\end{array}$ & 125 & 1.00 & 4.00 & 1.8880 & 1.04893 \\
\hline $\begin{array}{l}\text { My institution facilitates the process of accessing research } \\
\text { grants for academic research. }\end{array}$ & 125 & 1.00 & 4.00 & 2.4160 & .89067 \\
\hline $\begin{array}{l}\text { I now have an easier access to foreign journals for the } \\
\text { publication of my research papers than before. }\end{array}$ & 125 & 1.00 & 4.00 & 2.9120 & .97564 \\
\hline $\begin{array}{l}\text { It has now become easier for academics to publish in } \\
\text { foreign journals than before. }\end{array}$ & 125 & 1.00 & 4.00 & 3.0960 & .87459 \\
\hline Valid N (listwise) & 125 & & & & \\
\hline
\end{tabular}

Source: SPSS Output

In Table 3, the mean score of 1.88 shows an average rating by the respondents that they have benefited from international research grants to fund their academic research. Also, the mean score of 2.41 indicate an average rating by the respondents that their institutions facilitates the process of accessing research grants for academic research. However, the mean scores of 2.91 and 3.09 respectively shows that the respondents now have an easier 
access to foreign journals for the publication of their research papers than before and that it has now become easier for academics to publish in foreign journals than before.

Table 4 Summary of descriptive statistics on academic staff development

\begin{tabular}{|l|l|r|r|r|c|}
\hline & $\mathrm{N}$ & \multicolumn{1}{|c|}{ Minimum } & Maximum & \multicolumn{1}{c|}{ Mean } & \multicolumn{1}{c|}{ Std. Deviation } \\
\hline Academic Staff Development & 125 & 1.00 & 4.00 & 2.5307 & .53076 \\
\hline Continuous Professional Development & 125 & 1.00 & 4.00 & 2.4873 & .64411 \\
\hline Research Advancement & 125 & 1.00 & 4.00 & 2.5740 & .57679 \\
\hline Valid N (listwise) & 125 & & & & \\
\hline
\end{tabular}

Source: SPSS Output

Table 4 shows the cumulative mean scores of the dimensions of Academic Staff Development. The table shows that the level of Academic Staff Development in the tertiary institutions studied is high $(\mathrm{x}=2.53)$. Specifically, of the two measures of Academic Staff Development, only Research Advancement is high with a mean rating of 2.57, while Continuous Professional Development is rated as average with a mean score of 2.48.

\subsection{Secondary Analysis}

The correlation analysis was interpreted based on Guiford's (1956) scale given in Irving $(2005$, p. 16) thus:

(a) $<.20=$ slight correlation, almost negligible;

(b) .20 to $.40=$ low correlation, definite but small relationship;

(c) .40 to $.70=$ moderate correlation, substantial relationship;

(d) .70 to $.90=$ high correlation, marked relationship; and

(e) $>.90=$ very high correlation, very dependable relationship.

Research question 1: How does technological globalization influence continuous professional development in tertiary institutions in Rivers State?

The first research question sought to ascertain the influence of technological globalization on continuous professional development. The result of the analysis is shown on table 5.

Table 5. Correlations on Technological Globalization and Continuous Professional Development

\begin{tabular}{|l|l|r|r|}
\hline \multicolumn{2}{|c|}{} & \multicolumn{1}{|c|}{$\begin{array}{l}\text { Technological } \\
\text { Globalization }\end{array}$} & $\begin{array}{l}\text { Continuous } \\
\text { Development }\end{array}$ \\
\hline \multirow{2}{*}{ Technological Globalization } & Pearson Correlation & 1 & $.399^{* *}$ \\
\cline { 2 - 5 } & Sig. (2-tailed) & & .000 \\
\cline { 2 - 5 } & $\mathrm{N}$ & 125 & 125 \\
\hline $\begin{array}{l}\text { Continous } \\
\text { Developmen }\end{array}$ & Professional & $.399^{* *}$ & \multicolumn{1}{c|}{1} \\
\cline { 2 - 5 } & Sig. (2-tailed) & .000 & 125 \\
\cline { 2 - 5 } & $\mathrm{N}$ & 125 & \multicolumn{1}{c|}{125} \\
\hline
\end{tabular}

**. Correlation is significant at the 0.01 level (2-tailed).

Source: SPSS Output

From table 5 shown above, the $\mathrm{r}$ coefficient of .399 indicates a low correlation, but a definite small relationship between Technological Globalization and Continuous Professional Development in the institutions of the respondents.

Research question 2: In what ways does technological globalization influence research advancement in tertiary institutions in Rivers State?

The second research question sought to ascertain the influence of technological globalization on research advancement. The result of the analysis is shown on table 6 .

Table 6. Correlations on Technological Globalization and Research Advancement

\begin{tabular}{|l|l|r|r|}
\hline \multicolumn{2}{|l|}{} & \multicolumn{1}{c|}{$\begin{array}{c}\text { Technological } \\
\text { Globalization }\end{array}$} & Research Advancement \\
\hline \multirow{3}{*}{ Technological Globalization } & Pearson Correlation & 1 & $.284^{* *}$ \\
\cline { 2 - 4 } & Sig. (2-tailed) & 125 & .001 \\
\cline { 2 - 4 } & $\mathrm{N}$ & $.284^{* *}$ & 125 \\
\hline \multirow{2}{*}{ Research Advancement } & Pearson Correlation & .001 & 1 \\
\cline { 2 - 4 } & Sig. (2-tailed) & 125 & 125 \\
\cline { 2 - 4 } & $\mathrm{N}$ & & \\
\hline
\end{tabular}

**. Correlation is significant at the 0.01 level (2-tailed).

Source: SPSS Output

The $\mathrm{r}$ coefficient of .284 as shown in Table 6 indicates that there is a low correlation, but a definite small relationship between Technological Globalization and Research Advancement in the institutions of the 
respondents.

\subsection{Results of Test of Hypotheses}

Decision Rule

The significance level is determined at a $99 \%$ interval margin of 0.01 . Therefore:

If the $\mathrm{p}$ - value is $\leq 0.01$, reject the null hypothesis

If the $\mathrm{p}$-value is $\geq 0.01$, accept the null hypothesis

Table 7. Test of hypotheses

\begin{tabular}{|l|l|l|l|l|}
\hline \multicolumn{1}{|c|}{ Null Hypotheses } & R & $\begin{array}{c}\text { P- } \\
\text { Value }\end{array}$ & Conclusion & Decision \\
\hline $\begin{array}{l}\mathrm{H}_{\mathrm{o}} \text { : There is no significant relationship between technological } \\
\text { globalization and continuous professional development in tertiary } \\
\text { institutions in Rivers State. }\end{array}$ & $.399^{* *}$ & 0.000 & Significant & Reject \\
\hline $\begin{array}{l}\mathrm{H}_{\mathrm{o}} \text { 2: There is no significant relationship between technological } \\
\text { globalization and research advancement in higher institutions in } \\
\text { Rivers State. }\end{array}$ & $.284^{* *}$ & 0.001 & Significant & Reject \\
\hline
\end{tabular}

**. Correlation is significant at the 0.01 level (2-tailed).

Source: SPSS Output

As shown in Table 7, the calculated p-value for the two stated null hypothesis are .000 and .001 respectively which is less than 0.01 , showing a significant relationship. Therefore, the stated null hypotheses are rejected while the alternate hypothesis is accepted, meaning that there is a significant relationship between technological globalization and continuous professional development and research advancement in tertiary institutions in Rivers State.

\section{Discussion of Findings}

9.1. Technological Globalization and Continuous Professional Development in Tertiary Institutions in Rivers State

The analyzed data show the level of appreciation of technological globalization by academic staff of tertiary institutions in Rivers State with a high mean rating of 2.77. The mean score of 3.20 shows a high awareness of the different ICT tools that are available to make the respondents' work as academics easier. The institutions of the respondents have a high rating with the acquisition of the technological equipment needed to improve teaching and learning with the mean score of 2.55. Also, the mean score of 2.47 indicate an average in the training of the respondents by their various institutions in the use of ICT to aid their work as academics. The mean score of 2.88 show a high rating that the respondents have taken full advantage of technology in the performance of their duties as academics. The $r$ coefficient values from the research question and hypothesis on technological globalization and continuous professional development indicate a significant relationship between the individual variables. This buttresses the study by Ojedele, Oyekan and Oresajo (2015) which concluded that this millennium has witnessed a shift in learning process in higher institutions, and that this shift is due to the globalization trend and alignment thus not only situating higher education learning in the physical environment alone but also on virtual, online and electronic system. The gains of globalization in the area of technological advancement was also supported by Pwadura, Asapeo and Plockey (2017) that there is generally a high level of ICT skills among lecturers in computer usage, and further established that for the past decade, lecturers have been using e-resources but less frequently. The study also revealed that majority $88.9 \%$ of lecturers make significant use of the databases especially Science Direct mostly for educational /teaching purposes while $73.3 \%$ of them do so by accessing and using full text journal articles. It also came out clearly that lecturers found the eresources training very beneficial and recommended the Library should periodically organize information literacy workshops/seminar for staff, which can be done two or three times in a year.

\subsection{Technological Globalization and Research Advancement in Tertiary Institutions in Rivers State}

The mean score of 3.20 shows a high awareness of the different ICT tools that are available to make the respondents' work as academics easier. The institutions of the respondents have a high rating with the acquisition of the technological equipment needed to improve teaching and learning with the mean score of 2.55. Also, the mean score of 2.47 indicate an average in the training of the respondents by their various institutions in the use of ICT to aid their work as academics. The mean score of 2.88 show a high rating that the respondents have taken full advantage of technology in the performance of their duties as academics. In research advancement, the mean score of 1.88 shows an average rating by the respondents that they have benefited from international research grants to fund their academic research. Also, the mean score of 2.41 indicates an average rating by the respondents that their institutions facilitates the process of accessing research grants for academic 
research. However, the mean scores of 2.91 and 3.09 respectively show that the respondents now have an easier access to foreign journals for the publication of their research papers than before and that it has now become easier for academics to publish in foreign journals than before. The $r$ coefficient values from the research question and p-value for the hypothesis on technological globalization and research advancement indicate a positive and significant relationship between the individual variables. The study therefore corroborates the study of Okoli (2013) that globalization has over time given an opening to developed countries to invest lots of human and material resources into research and publication which is the secret of their development. It was buttressed that research and publications are continuous educational activities. Through research and publication, they transform their societies, not minding the amount of resources involved and they enjoy the benefits of these academic pursuits. These benefits accrue from advancement in research and development, science and technology, new technologies and innovations. Since many African governments do not make available the type of money needed for the kind of researches that make for sustainable development, tertiary institutions can take advantage of the gains of globalization to enhance research advancements.

\section{Conclusion}

The study concluded that as tertiary institutions in Rivers State acquire the needed information and communication technology (ICT), and train academic staff members in the use of ICT which has become imperative due to technological globalization, lecturers will become better equipped to deliver quality service in line with the benefits of continuous professional development. Subsequently, lecturers will become better positioned to publish their research outcomes through online publication platforms and connect with academics globally through research advancement opportunities.

\section{Recommendations}

Based on the findings of the study, the following recommendations were made:

1. Tertiary institutions in Rivers State should establish or equip functional ICT centres, and encourage academic staff members to gain the basic knowledge of ICT to enhance both teaching and research.

2. The school authorities should ensure functional and fully automated libraries with online access provided for academic staff members.

\section{References}

Aina, E. H. \& Reuben, D. (2014). "Effects of Globalization on Human Resource Development and Management in Nigeria", Education and Science Journal, 4 (1), 136 -142.

Almendarez, L. (2011), "Human Capital Theory: Implications for Educational Development". [Online] Available: www.Open.Uwi.Edu/.../Belize/Conference/Papers2010/Almendarez.Html (11/9/2018).

Chabaya, R. A. (2015), "Academic Staff Development in Higher Education Institutions: A Case Study of Zimbabwe State Universities", Ph.D. Thesis, Department of Curriculum Studies, University of South Africa. [Online] Available: Uir.Unisa.Ac.Za/Bitstream/Handle/10500/21930/Thesis_Chabaya_Ra.Pdf? (09/7/2018).

Columbus, O. (2018), "The Impact of Globalization in the Formation of Militant Groups in the Niger Delta", Nigerian Journal of Oil and Gas Technology, 3 (2), 1-13.

Flippo, E. B. (1976), Principles of personnel management. (4th ed.). Tokyo: Tosho Printing.

Graham, H. T. \& Bennett, R. (1988), Human resources management. (9th ed.). London: Pitman Publishing.

Holland, J. \& Holland, J. (2010), "Globalization of Instruction: Developing Intellectual Capital”, In Saez, P. L., De'Castro, G. M., Lopez, J. E. N. \& Verde, M. D. (2010), Intellectual capital and technological innovation: Knowledge-based theory and practice. New York: Hershey.

Imhonopi, D. \& Urim, U. M. (2014), "The Impact of globalization on the educational system in Nigeria. (Online). Available covenantuniversity.edu.Ng/profiles/IMHONOPI-DAVID/Theimpact-of... (28/6/2018).

Irving, J. A. (2005), "Servant leadership and the effectiveness of teams", Ph. D. Thesis, The School of Leadership Studies, Regent University.

Jelilov, G., Aleshinloye, M. F. \& Önder, S. (2016), Education as a key to economic growth and development in Nigeria", The International Journal of Social Sciences and Humanities Invention, 3(2), 1862-1868.

Kaegon, L. E. S. \& Nwikina, L. (2016), "Globalization as a Strategic Tool for Nigerian higher education. In Uche, C. M., Anyamele, S. C., Nwikina, L. \& Meeyinikor, J. N. D. (2016), Administration and organization of higher education. Port Harcourt: University of Port Harcourt Press.

Merriam Webster. [Online] Available: Https://Www.Merriam-Webster.Com/Dictionary) (10/7/2018).

Ojedele, P. K., Oyekan, O. A. \& Oresajo, N. O. (2015), "Impact Of Globalization On Higher Education In Nigeria, Journal of Educational Policy and Entrepreneurial Research, 2(7), 10-18.

Okoli, N. (2013), Universities and Globalisation Flows: African Experience, American Journal of Educational Research, 1(2), 58-62.

Olotu, O. A. (2013), "ICT and Globalization”, A Paper Presented at a Staff Development Programme for 
Administrative Staff of NGOs in Rivers State.

Olu, A. (2012), "Re-inventing the Nigerian education system for productivity improvements", Academic Research International, 2 (3), 482-489.

Pargaru, I., Gherghina, R. \& Duca, I. (2009), "The role of education in the knowledge-based society during the economic crisis, Annales Universitatis Apulensis Series Oeconomica, 11(2) 646-651.

Peretomode, V. F. \& Chukwuma, R. A. (2016), “Manpower development and lecturers' productivity in tertiary institutions in Nigeria. European Scientific Journal, 8(13), 16-22.

Pwadura, J., Asapeo, A. \& Plockey, F. D. (2017), Evaluation of use of e-resources by academic staff of Navrongo campus of university for development studies through workplace information literacy programmes, library philosophy and practice. [Online] Available: Http://Digitalcommons.Unl.Edu/Libphilprac/1538 (18/9/2018).

Samoszuk, S. (2018), "Human Capital Theory: Characteristics and Investment. [Online] Available: Https:/Study.Com/Academy/Lesson/Human- Capital-Theory (31/7/2018).

Tan, E. (2014), "Human Capital Theory: A Holistic Criticism, Review of Educational Research, 84(3), 411-445.

The Enotes (2011), "Pros and Cons of Technological Globalization". [Online] Available: Https://Www.Enotes.Com/Homework-Help/Identify-Pros-Cons-Technology-Relation-401473 (9/8/2018).

The Levin Institute (2016), "Globalization 101". [Online] Available: Www.Levininstitute.Org/EducationalPrograms/Globalization101 (08/11/2017).

The Simple Economist (2017), "Human Capital Theory". [Online] Available: Simpleeconomist.Com/HumanCapital-Theory $(31 / 7 / 2018)$. 